\title{
HUBUNGAN DUKUNGAN KELUARGA TERHADAP PROSES KESEMBUHAN PASIEN TUBERKOLOSIS PARU DI WILAYAH KERJA PUSKESMAS RAHUNING KECAMATAN RAHUNING KABUPATEN ASAHAN TAHUN 2016
}

\author{
JUWITA YANTI PAKPAHAN \\ Akademi Keperawatan Sri Bunga Tanjung \\ juwitayantipakpahan2186@gmail.com
}

\begin{abstract}
The success of tuberculosis treatment depends on the patient's knowledge and support from the family. No effort from oneself or motivation from families who do not provide complete support for treatment will affect patient compliance to take medication. Then a study was conducted to determine whether there was a relationship between family support and the healing process of pulmonary tuberculosis patients in the Rahuning Health Center Work Area, Rahuning District, Asahan Regency in 2016. This research was conducted in July-September 2016 with a population of 32 respondents. The sampling is done by using total sampling. The results of this study found that of the 15 respondents who received emotional support, all of them got cured compared to those who did not support 6 respondents from 8 respondents, who did not support 1 respondent from 9 respondents. Of the 15 respondents who received information support, all of them got cured compared to those who did not support 6 respondents out of 10 respondents, who did not support 1 respondent out of 9 respondents. Of the 10 respondents who received instrumental support, all of them got cured compared to those who did not support 11 respondents from 14 respondents, who did not support 1 respondent out of 8 respondents. Of the 13 respondents who received emotional support, all of them were cured, compared to those who were less supportive, 9 of the 15 respondents, who did not support the patient with appreciation, did not experience healing at all. This research is expected to provide benefits for families in assisting patients in obtaining healing by providing emotional support, information support, instrumental support and appreciation support about the importance of family support in helping to increase patient knowledge so that it can affect healing.
\end{abstract}

Keywords: Family Support, Healing of Pulmonary TB Patients.

Abstrak: Keberhasilan pengobatan tuberculosis tergantung pada pengetahuan pasien dan dukungan dari keluarga. Tidak ada upaya dari diri sendiri atau motivasi dari keluarga yang kurang memberikan dukungan untuk berobat secara tuntas akan mempengaruhi kepatuhan pasien untuk mengkonsumsi obat. Maka dilakukan penelitian tentang mengetahui apakah ada hubungan dukungan keluarga terhadap proses kesembuhan pasien Tuberkolosis Paru Di Wilayah Kerja Puskesmas Rahuning Kecamatan Rahuning Kabupaten Asahan Tahun 2016. Penelitian ini dilakukan pada Juli-September 2016 dengan populasi 32 responden. Dalam pengambilan sampel dilakukan dengan menggunakan total sampling. Hasil penelitian ini didapat bahwa dari 15 responden yang mendapat dukungan emosional seluruhnya mendapatkan kesembuhan dibanding dengan kurang mendukung 6 responden dari 8 responden, yang tidak mendukung 1 responden dari 9 responden. Dari 15 responden yang mendapat dukungan informasi seluruhnya mendapatkan kesembuhan dibanding dengan kurang mendukung 6 responden dari 10 responden, yang tidak mendukung 1 responden dari 9 
responden. Dari 10 responden yang mendapat dukungan instrumentalia seluruhnya mendapatkan kesembuhan dibanding dengan kurang mendukung 11 responden dari 14 responden, yang tidak mendukung 1 responden dari 8 responden. Dari 13 responden yang mendapat dukungan emosional seluruhnya mendapatkan kesembuhan dibanding dengan kurang mendukung 9 responden dari 15 responden, yang tidak mendukung dengan penghargaan pasien sama sekali tidak mengalami kesembuhan. Penelitian ini diharapkan dapat memberikan manfaat untuk keluarga dalam membantu pasien dalam memperoleh kesembuhan dengan memberikan dukungan emosional, dukungan informasi, dukungan instrumentalia dan dukungan penghargaan tentang pentingnya dukungan keluarga dalam membantu untuk menambah pengetahuan pasien sehingga dapat mempengaruhi kesembuhan.

Kata Kunci: Dukungan Keluarga, Kesembuhan Pasien TB Paru.

\section{A. Pendahuluan}

Tuberkulosis (TB) paru yaitu salah satu penyakit menular yang menyerang organ paru-paru. TB paru diperkirakan sudah ada di dunia sejak 5000 tahun sebelum masehi. Kemajuan dalam penemuan dan pengendalian penyakit TB Paru sudah ada sejak 2 abad terakhir (Pusat data dan Informasi Kementrian Kesehatan Republik Indonesia, 2015). Walaupun demikian, sebagian besar negara-negara di dunia belum berhasil mengendalikan penyakit TB paru. Angka kesakitan dan kematian akibat penyakit TB paru cenderung menetap dan meningkat (Widoyono, 2011).

WHO (2010) menunjukkan bahwa ada 22 negara dengan insiden terhadap TB (High Burden of TB Number) daya estimasi sebanyak 9,4 juta jiwa mengidap penyakit TB paru dan Indonesia menempati urutan kelima teratas. Total kejadian di Indonesia pada tahun 2009 mencapai 5000 dari total populasi 229.965 jiwa. Departemen Kesehatan Republik Indonesia tahun 2007 melaporkan bahwa angka kematian akibat TB paru ini diperkirakan 95\% terjadi di negara yang sedang berkembang. Di Indonesia, Jawa Tengah merupakan salah satu propinsi yang menempati urutan kelima tertinggi prevalensi penyakit TB. Tahun 2012 prevalensi TB Paru per 100.000 penduduk adalah sebesar 10,64\%. (Dinas Kesehatan Provinsi Jawa Tengah, 2013).

Penanganan terhadap tingginya prevalansi TB paru tersebut harus dilakukan untuk mengendalikan penyakit TB Paru, salah satunya dengan pengobatan. Untuk mencapai kesembuhan sangat penting bagi penderita TB Paru memiliki pengetahuan yang baik tentang penyakitnya (Aditama \& Aris, 2013). Pengetahuan tersebut dalam hal keteraturan, kelengkapan dan kepatuhan dalam minum Obat Anti Tuberkulosis (OAT). Sebaliknya, jika pengobatan tidak teratur dan kombinasi OAT tidak lengkap akan menimbulkan kegagalan pengobatan sehingga mengakibatkan Mycobacterium Tuberculosis dapat menjadi kebal sehingga menimbulkan terjadinya kasus MDR (Multidrug Resistence) TB paru serta akan menjadi sumber penularan untuk orang lain (Anugerah, 2007).

Keberhasilan pengobatan tuberculosis tergantung pada pengetahuan pasien dan dukungan dari keluarga. Tidak ada upaya dari diri sendiri atau motivasi dari keluarga yang kurang memberikan dukungan untuk berobat secara tuntas akan mempengaruhi kepatuhan pasien untuk mengkonsumsi obat. Apabila ini dibiarkan, dampak yang akan muncul jika penderita berhenti minum obat adalah munculnya kuman tuberculosis yang resisten terhadap obat, jika ini terus terjadi dan kuman tersebut terus menyebar pengendalian obat tuberculosis akan semakin sulit dilaksanakan dan meningkatnya angka kematian terus bertambah akibat penyakit tuberculosis (Amin dan Bahar, 2007). 
Studi pendahuluan yang dilakukan tanggal 19 Juni 2019 di Puskesmas Rahuning, dengan melakukan wawancara terhadap lima pasien. Pernyataan tiap pasien tersebut adalah mereka sudah diberikan penyuluhan tentang TB, akan tetapi hanya tiga pasien diantaranya cukup mengetahui tentang penyakit TB paru yang meliputi: cara penularan, gejala, penatalaksanaan pengobatan, pencegahan penularan serta mereka meyakini kesembuhan penyakitnya. Dua pasien lainya hanya mengetahui tentang cara pengobatan, penularan serta kurang yakin terhadap kesembuhan penyakitnya. Berdasarkan latar belakang diatas maka peneliti tertarik melakukan penelitian tentang Hubungan Dukungan Keluarga Terhadap Proses Kesembuhan Pasien Tuberkolosis Paru Di Wilayah Kerja Puskesmas Rahuning Kecamatan Rahuning Kabupaten Asahan Tahun 2016.

\section{B. Metodologi Penelitian}

Jenis penelitian ini adalah cross sectional yaitu merupakan rancangan penelitian dengan melakukan pengamatan pada saat bersamaan (Hidayat.A.A, 2009). Analisa data yang digunakan adalah Analisa Univariat dan analisa bivariat. Populasi dalam penelitian ini adalah seluruh penderita TB Paru di wilayah kerja Puskesmas Rahuning Kabupaten Asahan Tahun 2016. Dalam penelitian ini pengambilan sampel dilakukan dengan cara Total Sampling yaitu seluruh populasi dijadikan sampel : 32 sampel

\section{Hasil Dan Pembahasan \\ 1. Hasil Penelitian}

Tabel 1.

Distribusi Frekuensi Pasien Tuberkolosis Paru Di Wilayah Kerja Puskesmas Rahuning Kecamatan Rahuning Kabupaten Asahan Tahun 2016 Berdasarkan Pendidikan

\begin{tabular}{cccc}
\hline No & Pendidikan & f & $\%$ \\
\hline 1 & SD & 3 & 9,4 \\
\hline 2 & SMP & 8 & 25 \\
\hline 3 & SMA & 17 & 53,1 \\
\hline 4 & PT & 4 & 12,5 \\
\hline & Jumlah & 32 & 100
\end{tabular}

Berdasarkan Tabel 1. diperoleh data responden mayoritas memiliki pendidikan SMA yaitu 17 orang $(53,1 \%)$ sedangkan minoritas memiliki pendidikan SD yaitu 3 orang $(9,4 \%)$.

Tabel 2.

Distribusi Frekuensi Pasien Tuberkolosis Paru Di Wilayah Kerja Puskesmas Rahuning Kecamatan Rahuning Kabupaten Asahan Tahun 2016 Berdasarkan

Pekerjaan

\begin{tabular}{cccc}
\hline No & Pekerjaan & f & $\%$ \\
\hline 1 & PNS & 3 & 9,4 \\
\hline 2 & Pegawai Swasta & 7 & 21,9 \\
\hline 3 & Pedagang & 5 & 15,6 \\
\hline 4 & Wiraswasta & 12 & 37,5 \\
\hline 5 & IRT & 5 & 15,6 \\
\hline & Jumlah & 32 & 100 \\
\hline
\end{tabular}


Berdasarkan Tabel 2. diperoleh data responden mayoritas mempunyai pekerjaan sebagai wiraswasta yaitu 12 orang $(37,5 \%)$ sedangkan minoritas mempunyai pekerjaan sebagai PNS yaitu 3 orang $(9,4 \%)$.

\section{Tabel 3.}

Distribusi Frekuensi Pasien Tuberkolosis Paru Di Wilayah Kerja Puskesmas Rahuning Kecamatan Rahuning Kabupaten Asahan Tahun 2016 Berdasarkan

\begin{tabular}{cccc}
\multicolumn{5}{c}{ Usia } \\
\hline No & Usia & F & $\%$ \\
\hline 1 & $19-30$ tahun & 11 & 34,4 \\
\hline 2 & $31-45$ tahun & 12 & 37,5 \\
\hline 3 & $>45$ tahun & 9 & 28,1 \\
\hline & Jumlah & 32 & 100
\end{tabular}

Berdasarkan Tabel .3. diperoleh data responden mayoritas memiliki usia $31-45$ tahun yaitu 12 orang $(37,5 \%)$ sedangkan minoritas memiliki usia $>45$ tahun yaitu 9 orang $(28,1 \%)$.

Tabel 4.

Distribusi Frekuensi Dukungan Emosional Pada Pasien Tuberkolosis Paru Di Wilayah Kerja Puskesmas Rahuning Kecamatan Rahuning Kabupaten Asahan Tahun 2016

\begin{tabular}{cccc}
\hline No & Dukungan Emosional & F & $\%$ \\
\hline 1 & Mendukung & 15 & 46,9 \\
\hline 2 & Kurang Mendukung & 8 & 25 \\
\hline 3 & Tidak Mendukung & 9 & 28,1 \\
\hline & Jumlah & 32 & 100 \\
\hline
\end{tabular}

Berdasarkan Tabel 4. diperoleh data responden mayoritas mendukung secara emosional yaitu 15 orang $(46,9 \%)$ sedangkan minoritas kurang mendukung yaitu sebanyak 8 orang $(25 \%)$.

Tabel 5.

Distribusi Frekuensi Dukungan Informasi Pada Pasien Tuberkolosis Paru Di Wilayah Kerja Puskesmas Rahuning Kecamatan Rahuning Kabupaten Asahan

Tahun 2016

\begin{tabular}{cccc}
\hline No & Dukungan Informasi & F & $\%$ \\
\hline 1 & Mendukung & 15 & 46,9 \\
\hline 2 & Kurang Mendukung & 10 & 31,3 \\
\hline 3 & Tidak Mendukung & 7 & 21,9 \\
\hline & Jumlah & 32 & 100 \\
\hline
\end{tabular}

Berdasarkan Tabel.5. diperoleh data responden mayoritas mendukung dengan informasi yaitu 15 orang $(46,9 \%)$ sedangkan minoritas tidak mendukung yaitu sebanyak 7 orang $(21,9 \%)$.

Tabel 6.

Distribusi Frekuensi Dukungan Instrumentalia Pada Pasien Tuberkolosis Paru

Di Wilayah Kerja Puskesmas Rahuning Kecamatan Rahuning Kabupaten Asahan Tahun 2016

\begin{tabular}{cccc}
\hline No & Dukungan Instrumentalia & F & $\%$ \\
\hline 1 & Mendukung & 10 & 31,3 \\
\hline 2 & Kurang Mendukung & 14 & 43,8 \\
\hline
\end{tabular}




\begin{tabular}{cccc}
\hline 3 & Tidak Mendukung & 8 & 25 \\
\hline Jumlah & 32 & 100 \\
\hline
\end{tabular}

Berdasarkan Tabel 6. diperoleh data responden mayoritas kurang mendukung secara instrumentalia yaitu 14 orang $(43,8 \%)$ sedangkan minoritas tidak mendukung yaitu sebanyak 8 orang $(25 \%)$.

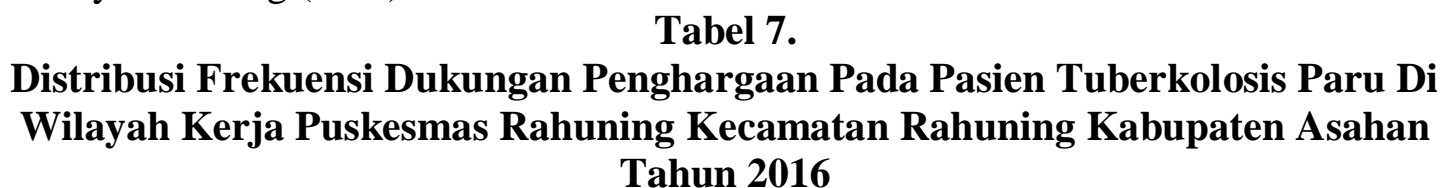

\begin{tabular}{cccc}
\hline No & Dukungan Penghargaan & F & $\%$ \\
\hline 1 & Mendukung & 13 & 40,6 \\
\hline 2 & Kurang Mendukung & 15 & 46,9 \\
\hline 3 & Tidak Mendukung & 4 & 12,5 \\
\hline & Jumlah & 32 & 100
\end{tabular}

Berdasarkan Tabel .7. diperoleh data responden mayoritas kurang mendukung secara penghargaan yaitu 15 orang $(46,9 \%)$ sedangkan minoritas tidak mendukung yaitu sebanyak 4 orang $(12,5 \%)$.

Tabel 8.

Distribusi Frekuensi Status Kesehatan Pasien Tuberkolosis Paru Di Wilayah Kerja Puskesmas Rahuning Kecamatan Rahuning Kabupaten Asahan Tahun 2016

\begin{tabular}{cccc}
\hline No & Status Kesehatan & F & $\%$ \\
\hline 1 & Sembuh & 22 & 68,8 \\
\hline 2 & Tidak Sembuh & 10 & 31,3 \\
\hline & Jumlah & 32 & 100 \\
\hline
\end{tabular}

Berdasarkan Tabel. 8. diperoleh data responden mayoritas status kesehatan sembuh yaitu 22 orang $(68,8 \%)$ sedangkan minoritas tidak sembuh yaitu sebanyak 10 orang $(31,3 \%)$.

Tabel.9.

Tabel Silang Dukungan Emosional Terhadap Kesembuhan Pasien Tuberkolosis Paru Di Wilayah Kerja Puskesmas Rahuning Kecamatan Rahuning Kabupaten Asahan Tahun 2016

\begin{tabular}{|c|c|c|c|c|c|}
\hline \multirow[b]{2}{*}{ No } & \multirow{2}{*}{$\begin{array}{l}\text { Dukungan } \\
\text { Emosional }\end{array}$} & \multicolumn{2}{|c|}{ Status Kesehatan } & \multirow[b]{2}{*}{$\mathrm{F}$} & \multirow[b]{2}{*}{$\%$} \\
\hline & & Sembuh & $\begin{array}{c}\text { Tidak } \\
\text { Sembuh }\end{array}$ & & \\
\hline 1 & Mendukung & 15 & 0 & 15 & 46,9 \\
\hline 2 & $\begin{array}{l}\text { Kurang } \\
\text { Mendukung }\end{array}$ & 6 & 2 & 8 & 25 \\
\hline 3 & $\begin{array}{l}\text { Tidak } \\
\text { Mendukung }\end{array}$ & 1 & 8 & 9 & 28,1 \\
\hline & Jumlah & 22 & 10 & 32 & 100 \\
\hline
\end{tabular}

Dari hasil tabel.9. diatas dapat diketahui bahwa dari 15 responden yang mendapat dukungan emosional seluruhnya mendapatkan kesembuhan dibanding dengan kurang mendukung 6 responden dari 8 responden, yang tidak mendukung 1 responden dari 9 responden .

Hal ini membuktikan ada hubungan yang sangat erat antara dukungan emosional yang diberikan kepada pasien baik dari keluarga maupun dari petugas kesehatan terhadap 
kesembuhan pasien TB paru di Wilayah Kerja Puskesmas Rahuning Kecamatan Rahuning Kabupaten Asahan tahun 2016.

Tabel.10.

Tabel Silang Dukungan Informasi Terhadap Kesembuhan Pasien Tuberkolosis Paru Di Wilayah Kerja Puskesmas Rahuning Kecamatan Rahuning Kabupaten Asahan Tahun 2016

\begin{tabular}{|r|l|c|r|c|c|}
\hline \multirow{2}{*}{ No } & \multirow{2}{*}{$\begin{array}{c}\text { Dukungan } \\
\text { Informasi }\end{array}$} & \multicolumn{2}{|c|}{ Status Kesehatan } & \multirow{2}{*}{ F } & \multirow{2}{*}{$\%$} \\
\cline { 3 - 4 } & Sembuh & $\begin{array}{c}\text { Tidak } \\
\text { Sembuh }\end{array}$ & & \\
\hline 1 & Mendukung & 15 & 0 & 15 & 46,9 \\
\hline 2 & $\begin{array}{l}\text { Kurang } \\
\text { Mendukung }\end{array}$ & 6 & 4 & 10 & 31,3 \\
\hline 3 & Tidak Mendukung & 1 & 6 & 7 & 21,9 \\
\hline & Jumlah & 22 & 10 & 32 & 100 \\
\hline
\end{tabular}

Dari hasil tabel.10. diatas dapat diketahui bahwa dari 15 responden yang mendapat dukungan informasi seluruhnya mendapatkan kesembuhan dibanding dengan kurang mendukung 6 responden dari 10 responden, yang tidak mendukung 1 responden dari 9 responden .

Hal ini membuktikan ada hubungan yang sangat erat antara dukungan informasi yang diberikan kepada pasien baik dari keluarga maupun dari petugas kesehatan terhadap kesembuhan pasien TB paru di Wilayah Kerja Puskesmas Rahuning Kecamatan Rahuning Kabupaten Asahan tahun 2016.

Tabel.1.

Tabel Silang Dukungan Instrumentalia Terhadap Kesembuhan Pasien Tuberkolosis Paru Di Wilayah Kerja Puskesmas Rahuning Kecamatan Rahuning Kabupaten Asahan Tahun 2016

\begin{tabular}{|c|c|c|c|c|c|}
\hline \multirow[b]{2}{*}{ No } & \multirow{2}{*}{$\begin{array}{c}\text { Dukungan } \\
\text { Instrumentalia }\end{array}$} & \multicolumn{2}{|c|}{ Status Kesehatan } & \multirow[b]{2}{*}{$\mathrm{F}$} & \multirow[b]{2}{*}{$\%$} \\
\hline & & Sembuh & $\begin{array}{c}\text { Tidak } \\
\text { Sembuh }\end{array}$ & & \\
\hline 1 & Mendukung & 10 & 0 & 10 & 31,3 \\
\hline 2 & $\begin{array}{l}\text { Kurang } \\
\text { Mendukung }\end{array}$ & 11 & 3 & 14 & 43,8 \\
\hline 3 & Tidak Mendukung & 1 & 7 & 8 & 25 \\
\hline & Jumlah & 22 & 10 & 32 & 100 \\
\hline
\end{tabular}

Dari hasil tabel.11.diatas dapat diketahui bahwa dari 10 responden yang mendapat dukungan instrumentalia seluruhnya mendapatkan kesembuhan dibanding dengan kurang mendukung 11 responden dari 14 responden, yang tidak mendukung 1 responden dari 8 responden .

Hal ini membuktikan ada hubungan yang sangat erat antara dukungan Instrumentalia yang diberikan kepada pasien baik dari keluarga maupun dari petugas kesehatan terhadap kesembuhan pasien TB paru di Wilayah Kerja Puskesmas Rahuning Kecamatan Rahuning Kabupaten Asahan tahun 2016.

Tabel.12.

Tabel Silang Dukungan Penghargaan Terhadap Kesembuhan Pasien Tuberkolosis Paru Di Wilayah Kerja Puskesmas Rahuning Kecamatan Rahuning Kabupaten Asahan Tahun 2016

\begin{tabular}{|c|c|c|r|c|c|}
\hline \multirow{2}{*}{ No } & Dukungan & \multicolumn{2}{|c|}{ Status Kesehatan } & \multirow{2}{*}{$\mathrm{f}$} & \multirow{2}{*}{$\%$} \\
\cline { 3 - 4 } & Penghargaan & Sembuh & Tidak & & \\
\hline
\end{tabular}




\begin{tabular}{|c|l|c|c|c|c|}
\hline & & & Sembuh & & \\
\hline 1 & Mendukung & 13 & 0 & 13 & 40,6 \\
\hline 2 & $\begin{array}{l}\text { Kurang } \\
\text { Mendukung }\end{array}$ & 9 & 6 & 15 & 46,9 \\
\hline 3 & Tidak Mendukung & 0 & 4 & 4 & 12,5 \\
\hline & Jumlah & 22 & 10 & 32 & 100 \\
\hline
\end{tabular}

Dari hasil tabel.9. diatas dapat diketahui bahwa dari 13 responden yang mendapat dukungan emosional seluruhnya mendapatkan kesembuhan dibanding dengan kurang mendukung 9 responden dari 15 responden, yang tidak mendukung dengan penghargaan pasien sama sekali tidak mengalami kesembuhan. Hal ini membuktikan ada hubungan yang sangat erat antara dukungan penghargaan yang diberikan kepada pasien baik dari keluarga maupun dari petugas kesehatan terhadap kesembuhan pasien TB paru di Wilayah Kerja Puskesmas Rahuning Kecamatan Rahuning Kabupaten Asahan tahun 2016.

\section{Pembahasan}

Berdasarkan hasil penelitian yang dilakukan mengenai hubungan dukungan keluarga terhadap proses kesembuhan pasien tuberkolosis paru maka dapat dibahas sebagai berikut : di Wilayah Kerja Puskesmas Rahuning Kecamatan Rahuning Kecamatan Rahuning Kabupaten Asahan Tahun 2016maka dapat disimpulkan bahwa dukungan keluarga sangat berperan penting dalam proses kesembuhan pasien tuberkolosis paru. Pasien yang mendapat dukungan emosional mempengaruhi proses kesembuhan pasien dimana dari 15 responden memperoleh kesembuhan dari tuberkolosis paru dibandingkan pasien yang tidak mendapat dukungan emosional tidak memperoleh kesembuhan dilihat dari besarnya jumlah yang tidak sembuh yaitu 8 dari 9 responden

Dukungan Informasi mempunyai peran penting dalam kesembuhan pasien penyakit dimana informasi ini memberikan dukungan dengan pengetahuan tentang halhal yang dapat membantu kesembuhan pasien TB Paru. Dengan dukungan informasi yang baik 15 responden mengalami kesembuhan keseluruhannya dibanding dengan tidak mendapat dukungan informasi yang hanya 1 responden saja yang mengalami kesembuhan. Instrumentalia merupakan peralatan yang sering di gunakan dalam proses mendukung kesembuhan pasien. Penggunaan instrumentalia dengan baik akan membantu proses kesembuhan pasien TB Paru. Dari 10 responden dengan dukungan isntrumentalia mendapat kesembuhan keseluruhannya diabnding dengan yang tidak mendukung.

Dukungan penghargaan juga sangat berperan besar dalam proses kesembuhan pasien. Penghargaan memberikan semangat kepada pasien dan membuang rasa tidak percaya diri terhadap penyakit yang dialaminya. Terlihat dari 4 responden yang tidak mendapat dukungan penghargaan keseluruhan responden tidak mengalami kesembuhan dibanding dengan yang mendapat dukungan kesembuhan yaitu 13 responden mengalami kesembuhan keseluruhannya. Maka dapat disimpulkan bahwa dukungan emosional, dukungan informasi, dukungan instrumentalia dan dukungan penghargaan berperan penting dalam proses kesembuhan pasien TB Paru. Walau diperlukan dukungan lain seperti pengobatan, sitirahat yang cukup serta nutrisi yang baimyaitu tinggi kalori tinggi protein. 


\section{Penutup}

Berdasarkan hasil tabel diatas maka dapat disimpulkan bahwa dukungan emosional, dukungan informasi, dukungan instrumentalia dan dukungan penghargaan berperan penting dalam prose kesembuhan pasien TB Paru. Walau diperlukan dukungan lain seperti pengobatan, istirahat yang cukup serta nutrisi yang baik yaitu tinggi kalori tinggi protein. Hasil penelitian ini dapat bermanfaat bagi penderita TB paru, keluarga, Tenaga Kesehatan dan Peneliti Lain agar informasi tentang pengetahuan TB paru dapat membantu penderita dalam proses kesembuhan dan mengetahui pentingnya mendapat dukungan dari keluarga, kemudian penelitian ini juga diharapkan dapat menambah ilmu pengetahuan bagi petugas kesehatan tentang hubungan dukungan keluarga terhadap proses kesembuhan penderita TB paru agar nantinya bisa memberikan edukasi untuk penderita TB paru untuk menambah pengetahuan bagi penderita dan penelitian ini juga diharapkan mampu menambah ilmu pengetahuan serta informasi bagi peneliti lain terkait hubungan dukungan keluarga terhadap proses kesembuhan TB paru sehingga dapat dihasilkan penelitian lainnya terkait aspek-aspek psikologis pada penderita TB paru yang dapat memberikan kontribusi pada ilmu pengetahuan dan khususnya untuk penanggulangan TB paru di Indonesia.

\section{Daftar Pustaka}

Bimantara Galuh. (2016). Tuberkulosis di Indonesia Terbanyak kedua di Dunia. Majalah kompas. 24 Maret 2016: Majalah online http J/print. kompas. com/baca/iptek/kesehatan/2016/03/24/Tuberkulo. (Diakses tanggal 22 Agustus 2016)

Bogdan, Robert \& Steven J. Taylor. (1992). Pengantar Metode Penelitian Kualitatif. Surabaya: Usaha Nasional.

Depkes Rl. (2007). Pedoman Nasional Penanggulangan Tuberkulosis. Jakarta : Gerdunas TB. Edisi 2 hal. 20-21

Depkes RI. ( 2008). Pedoman penaggulangan nasional TBC. Jakarta: Depkes RI.

Dinkesprov. Profil kesehatan jawa tengah tahun 2014.http://www.dinkesiatengprov.go.id/V2015/dokumen/piofil2014/Piofil 2014.pdf.

Febriasari, A. (2007). Hubungan Antara Dukungan Sosial dengan Penyesuaian Diri Remaja di Panti Asuhan AI Bisri Semarang Tahun 2007. Skripsi. (Tidak diterbitkan). Semarang. Universitas Negeri Semarang.

Fitria \& Febrianti. (2015). Hubungan Dukungan Keluarga Dengan Kepatuhan Minum Obat Pada Pasien Tuberkulosis Paru Di Wilayah Kerja Puskesmas Gading Rejo. Jurnal dunia kesehatan. Vol 5. No 1. Januari 2016.

Friedman, Marilyn M. (2010). Buku Ajar Keperawatan Keluarga : Riset, Teori Dan Praktek. Jakarta : EGC

Hendani, dkk. Hubungan Antara Persepsi Dukungan Keluarga Sebagai Pengawas Minum Obat Dan Efikasi Diri Penderita Tuberkulosis Di BKPM Semarang. Jurnal Psikologi Undip. Vol 13. No 1. April 2014.

Hastuti, dkk. (2014). Hubungan Dukungan Sosial Dengan Hidup Pada Penderita Tuberkulosis Paru Di Balai Kesehatan Kerja Masyarakat Provinsi Jawa Barat Tahun 2014 Jurnal Bhakti Kencana Medika. Vol 4. No 1. Maret 2014. Hal 1-74.

Kail, Robert .V \& Cavanaugh. J. C. (2000). Human Development : A life Span View 2th ed. United States : Wadsworth Thomson Leraning. 
Kementerian Kesehatan Republik Indonesia. (2014). Pedoman Nasional Pengendalian Tuberkulosis, Jakarta.

Kementerian Kesehatan Republik Indonesia. (2015). Profil Kesehatan Indonesia Tahun 2015. Jakarta: Kemeterian Kesehatan Republik Indonesia. 2016

Kementerian Kesehatan Republik Indonesia. (2016). TOSS TB: Temukan Obati Sampai Sembuh. Jakarta.

Kaplan, H.L, Sadock. ( 2006). Sinopsis Psikiatri, Ilmu Pengetahuan Perilaku Psikiatri Klinis. Edisi 7. Jilid II. Jakarta : Binaputra Aksara.

Levinson W. (2008). Review of medical microbiology and immunology. 10th ed. McGraw-Hill Companies. p366-49.

Linda Ewles \& Ina Simmet. (1992). Konsep Sehat. Jakarta'. Pusdiklat Pegawai Depkes Rl.

Moleong, Lexy. J. (2004). Metode Penelitian Kualitatif. Remaja Rosdakarya. Bandung Miles, B.B, \& A.M. Huberman. (1992). Analisa Data Kualitatif. Ul Press Jakarta

Megawangi, R. (1999). Membiarkan Berbeda: Sudut Pandang Baru Tentang Relasi Gender. Penerbit Mizan. Bandung.

Manuhara L. (2012). Evaluasi Tingkat Kepatuhan Penggunaan Obat Tuberkulosis Paru Pada

Nursalam.(2003). Konsep Dan Penerapan Metodologi Penelitian llmu Keperawatan: Pedoman Skripsi, Tesis Dan Instrumen Penelitian Keperawatan (Edisi Pertama). Jakarta: Salemba Medika.

Notoatmojo, Soekidjo. (2007). Promosi Kesehatan dan llmu Perilaku. Rineka Cipta. Jakarta.

Perhimpunan Dokter Paru Indonesia (PDPI). (2006). Asma: Pedoman Diagnosis \& Penatalaksanaan di Indonesia. Perhimpunan Dokter Paru Indonesia.

Poerwandari, E.K. (2005). Pendekatan Kualitatif untuk penelitian perilaku manusia. Jakarta : Lembaga Pengembangan Sarana Pengukuran dan pendidikan Psikologi Fakultas Psikologi Universitas Indonesia.

Polit \& Hungler. (1999). Nursing Research Principles and Methods. Philadelphia: Lippincott.

Potter \& Perry. (2005). Buku Ajar Fundamental Keperawatan : Konsep, Proses, Dan Praktik. Edisi 4. Volume 1. Alih Bahasa : Yasmin Asih, dkk. Jakarta : EGC.2005

Retni, (2010). Hubungan Dukungan Sosilal Keluarga Dengan Tingkat Kesembuhan Penderita Tuberkulosis Paru Di Puskesmas Umbulharji II Yogyakarta. Jurnal

Sarafino, E. P. (2006). Health Psychology : Biopsychosocial Interactions. Fifth Edition. USA: John Wiley \& Sons.

Sumantri, irman. (2007). Asuhan keperaatan Pada Pasien Dengan Gangguan Pernafasan, Jakarta: Salemba Medika

Smet, Bart. (1994). Psikologi Kesehatan. Jakarta : Grasindo

Setiadi. (2008). Keperawatan Keluarga. EGC, Jakarta

Setiawati Santun, Dermawan Agus Citra. (2008). Penuntun praktis Asuahan keperawatan Keluarga Cetakan I, Edisi ke 2. Jakarta: Trans Info Media.

Santa, dkk. (2009). Seri Asuhan Keperawatan Gangguan Sistem Pernafasan Akibat Infeksi. Jakarta: TIM. 